\title{
STUDI KOMPARATIF FISIOLOGIS PROBIOTIK LAKTAT DALAM BEBERAPA MEDIA CAIR GULA SEDERHANA
}

\author{
Nurmiati \\ Jurusan Biologi, Fakultas Matematika dan Ilmu Pengetahuan Alam \\ Universitas Andalas
}

\begin{abstract}
Several simple sugar liquid media were used to observe the growth of several lactic acid probiotic bacteria were usually used in food probiotic products. The required of the sugar of the bacteria were observed in liquid media consisting simple sugar such as glucose, fructose, lactose and sucrose by observing the population growth and the metabolite products. The lactic acid probiotic bacteria were used were Lactobacillus acidophilus, L. casei, L. plantarum, Streptococcus lactis, S. thermophilus, Leuconostoc mesentroides and Pediococcus acidilactisi. The analysis of the result obtained the growth of populations, the developments of the $\mathrm{pH}$ value and total acidity. The results showed that the respond of the probiotics in it's growth and development to the different simple sugar were vary. Glucose and sucrose are suitable simple sugar for all lactic acid probiotics. S.lactis showed in all media lower average of $\mathrm{pH}$-Value (2.43) than other bacteria after 4 weeks observation. The highest decreasing of $\mathrm{pH}$ Value achieved by L.acidophilus
\end{abstract}

Keywords : Lactic acid probiotic bacteria, Glucose, Sucrose, Fructose, Lactose

\section{DAFTAR PUSTAKA}

1. Fuller, Probiotic in Man and Animal. J. Appl, Bacteriol, 66. 365-378, (1989).

2. Henkenjohann K. und B. Muermann, Mikrobiologie der Gaerung und Getraenkeindustrie. Cena Verlag. Meckenheim, (1998).

3. Wed, 2004. Pentingnya probiotik bagi sistem kekebalan tubuh. http://group.or.id/ pipermail/Kb/2004-March/000551.html. 20-Desember 2005.

4. P. Czermak, (Edt). Lebensmittelbiotechnologie, Git Velag, Darmstadt, Germany, (1993).

5. N. Hidayat, I. Nurika, W. A. P. Dania, Membuat minuman prebiotik dan probiotik. Trubus. Agrisarana, Surabaya, (2006).
6. H. D. Belitz, und V. W. Grosch. Lehrbuch der Lebensmittelchemie. Springer Verlag. Berlin. Heidelberg. Germany (1987).

7. A. Jährig und W. Schade, Mikrobiologie der gaerungs und getränkeindustrie. Cena Verlag, Meckenheim, (1993).

8. G. Mueller, Mikrobiologie pflanzlicher Lebensmittel. Steinkopf Verlag, Darmstadt. Germany, (1974).

9. Sartorius, Mikrobiologische Untersuchung des Weines und die Betriebskontrolle im Grossbetrieb, Germany (1985).

10. Nurmiati, Perkembangan Populasi Mikroflora Dadih selama Fermentasi Susu Kerbau Mentah dan Pasteurisasi. Makalah Seminar Semirata BKS Perguruan Tinggi Negeri Wilayah Barat Bidang MIPA xIX Universitas Andalas, Padang (2005). 